\section{Jurnal Mitra Pendidikan (JMP Online)}

URL : http://e-jurnalmitrapendidikan.com
JMP Online

Vol. 4, No. 7, 420-435

(C) 2020 Kresna BIP. e-ISSN 2550-0481 p-ISSN 2614-7254

\title{
PEMANFAATAN LINGKUNGAN SEKOLAH SEBAGAI MEDIA PEMBELAJARAN UNTUK MENINGKATKAN PRESTASI BELAJAR SISWA DI SDN KOTA BARU LEWOLEBA
}

\author{
Aloysius Pendito Kerans \\ SD Negeri Kota Baru Lewoleba
}

INFORMASI ARTIKEL

Dikirim : 03 Juli 2020

Revisi pertama : 08 Juli 2020

Diterima : 15 Juli 2020

Tersedia online : 31 Juli 2020

Kata Kunci: Lingkungan, Media, Prestasi

Email:pendito12@gmail.com
ABSTRAK

Penelitian ini bertujuan untuk mengetahui pemanfaatan lingkungan sekolah sebagai media pembelajaran bagi guru dalam kegiatan belajar mengajar.

Hasil pelaksanaan siklus I pada pertemuan pertama dan kedua adalah dari hasil pengamatan observer mendapat nilai cukup pada kelas I sampai kelas VI dan pada pelaksanaan siklus II mendapat nilai baik sehingga dapat meningkatkan prestasi belajar baik siswa maupun guru. Penelitian ini pada dua mata pelajaran yaitu Matematika pada kelas I sampai kelas III dan IPA pada kelas IV sampai kelas VI. Pada siklus I prosentase nilai mencapai 36,11 sampai $41,66 \%$ sedangkan pada siklus II prosentase nilai mencapai 44,33 sampai $61,11 \%$.

Setelah membahas dari hasil penelitian ini, maka pemanfaatan lingkungan sekolah sebagi media pembelajaran dapat ditingkatkan lagi dimana kepala sekolah sebagai motivator dan siswa mendukung kegiatan pembelajaran yang digunakan oleh guru untuk meningkatkan prestasi belajar dan meningkatkan kualitas pendidikan di SDN Kota Baru Lewoleba. 


\section{PENDAHULUAN \\ Latar Belakang}

Lingkungan merupakan sumber belajar yang banyak berpengaruh terhadap proses pembelajaran yang berlangsung. Lingkungan merupakan bagian dari manusia khususnya bagi peserta didik untuk hidup dan berinteraksi dengan sesamanya. Lingkungan yang ada disekitar anak-anak merupakan salah satu sumber belajar yang dapat digunakan dalam proses pembelajaran. Dan apabila seorang guru mengajar dengan memanfaatkan lingkungan sebagai sumber belajar maka akan lebih bermakna karena para siswa dihadapkan pada kenyataan dan peristiwa yang sebenarnya. Menurut Suprihatin (2013: 16) segala macam sumber yang ada di luar diri seseorang (peserta didik) dan yang memungkinkan atau memudahkan terjadinya proses pembelajaran disebut sebagai sumber belajar.

Berdasarkan hasil pengamatan awal yang dilakukan di SDN Kota Baru Lewoleba, pembelajaran yang dilakukan selama ini masih bersifat berfokus pada guru. Pada umumnya guru dalam memberikan pelajaran hanya bertumpu pada media pembelajaran dan yang sering digunakan guru selama ini adalah buku paket sebagai sumber belajar. Tanpa disadari bahwa masih banyak sumber yang berasal dari lingkungan yang dapat dijadikan sebagai sumber belajar. Guru belum mengoptimalkan metode pembelajaran yang bervariasi sehingga keaktifan danmotivasi siswa terhadap pembelajaran masih rendah. Selama proses pembelajaran didalam kelas beberapa siswa mengobrol dengan teman sebangku dan tidak memperhatikan penjelasan guru. Guru sudah berusaha menyampaikan materi dengan baik, dengan suara yang jelas, menatap semua siswa dan menegur siswa jika tidak memperhatikan. Upaya guru ini belum berhasil memotivasi siswa untuk mengikuti pembelajaran dengan serius. Siswa merasa bosan dengan metode ceramah yang digunakan oleh guru selama ini. Hal tersebut menjadi salah satu faktor penyebab hasil belajar yang kurang optimal.

Tujuan memanfaatkan lingkungan sekitar agar pembelajaran yang berlangsung tidak membosankan dan siswa lebih paham benda-benda yang ada di sekitar lingkungan sekolah. Karena dengan membawa siswa langsung ketempatnya siswa akan lebih memahami apa-apa saja yang ada dilingkungan sekolah tersebut dan manfaat lingkungan sekolahnya. Siswa tidak hanya belajar dengan teori tetapi langsung melihat benda sekitar.

Dengan melihat masalah yang dihadapi guru, sebagai kepala sekolah juga merasa masalah ini adalah bagian dari masalah sekolah sehingga kepala sekolah akan mengambil judul tentang "Pemanfaatan Lingkungan Sekolah sebagai Media Pembelajaran untuk Meningkatkan Prestasi Belajar Siswa di SDN Kota Baru Lewoleba".

\section{Rumusan Masalah}

Berdasarkan latar belakang yang telah dikemukakan, maka rumusan masalah dalam penelitian ini adalah bagaimana pemanfaatan lingkungan sekolah sebagai media pembelajaran untuk meningkatkan prestasi belajar siswa di SDN Kota Baru Lewoleba?. 


\section{Tujuan Penelitian}

Sesuai dengan rumusan masalah diatas maka yang menjadi tujuan penelitian ini adalah :

1. Untuk mengetahui pemanfaatan lingkungan sekolah sebagai sumber belajar di SDN Kota Baru Lewoleba.

2. Untuk mengetahui kendala guru dalam pemanfaatan lingkungan sekolah sebagai sumber belajar di SDN Kota Baru Lewoleba.

3. Untuk mengetahui upaya apa untuk mengatasi kendala guru dalam pemanfaatan lingkungan sekolah sebagai sumber belajar di SDN Kota Baru Lewoleba.

\section{KAJIAN PUSTAKA \\ Lingkungan Sekolah Sebagai Sumber Belajar}

Belajar pada hakikatnya adalah suatu interaksi antara individu dan lingkungan. Lingkungan menyediakan rangsangan (stimulus) terhadap individu dan sebaliknya individu memberikan respon terhadap lingkungan. Dalam proses interaksi itu dapat terjadi perubahan pada diri individu berupa perubahan tingkah laku. Dapat juga terjadi, individu menyebabkan terjadinya perubahan pada lingkungan, baik yang positif atau bersifat negatif. Hal ini menunjukkan, bahwa fungsi lingkungan merupakan faktor yang penting dalam proses belajar mengajar. Tokoh-tokoh pendidikan masa lampau berpandangan bahwa faktor lingkungan sangat bermakna dan dijadikan sebagai landasan dalam mengembangkan konsep pendidikan dan pengajaran. Misalnya Rousseau dengan teorinya "Kembali ke Alam" menunjukkan betapa pentingnya pengaruh alam terhadap perkembangan anak didik. Karena itu pendidikan anak harus dilaksanakan di lingkungan alam yang bersih, tenang, suasana menyenangkan, dan segar, sehingga sang anak tumbuh sebagai manusia yang baik (Ardiyani, Avira Mufti. 2011). Ligthart terkenal dengan "Pengajaran Alam Sekitar". Menurut tokoh ini pendidikan sebaiknya disesuaikan dengan keadaan alam sekitar. Alam sekitar (Milleu) adalah segala sesuatu yang ada di sekitar kita. Pengajaran berdasarkan alam sekitar akan membantu anak didik untuk menyesuaikan dirinya dengan keadaan sekitarnya. Decroly dikenal dengan teorinya, bahwa "Sekolah adalah dari kehidupan dan untuk kehidupan" (Ecole pour la par lavie). Dikemukakan, bahwa "bawalah kehidupan ke dalam sekolah agar kelak anak didik dapat hidup di masyarakat". Pandangan ketiga tokoh pendidikan tersebut sedikit banyak menggambarkan, bahwa lingkungan merupakan dasar pendidikan/pengajaran yang penting, bahkan dengan dasar ini dapat dikembangkan suatu model persekolahan yang berorientasi pada lingkungan masyarakat (Amalia, Nurin Hanifati. 2015) menjelaskan bahwa: Alam sekitar dan lingkungan merupakan dua istilah yang sangat erat kaitannya tetapi berbeda secara gradual. Alam sekitar mencakup segala hal yang ada di sekitar kita, baik yang jauh maupun yang dekat letaknya, baik masa silam maupun yang akan datang tidak terikat pada dimensi waktu dan tempat. Lingkungan adalah sesuatu yang ada di alam sekitar yang memiliki makna dan atau pengaruh tertentu kepada individu.

Selanjutnya, Hidayat, A. (2010:1) mengungkapkan bahwa: Lingkungan adalah seluruh faktor luar yang mempengaruhi suatu organisme; faktor-faktor ini dapat berupa organisme hidup (biotic factor) atau variabel-variabel yang tidak 
hidup (abiotic factor) misalnya suhu, curah hujan, panjangnya siang, angin, serta arus-arus laut. Interaksi-interaksi antara organisme-organisme dengan kedua faktor biotik dan abiotik membentuk suatu ekosistem.

Dalam Kamus Umum Bahasa Indonesia (KUBI) lingkungan diartikan sebagai bulatan yang melingkungi (melingkari). Pengertian lainnya yaitu sekalian yang terlingkung di suatu daerah. Dalam Kamus Bahasa Inggris peristilahan lingkungan ini cukup beragam diantaranya ada istilah circle, area, surrounding, sphere, domain, range, dan environment, yang artinya kurang lebih berkaitan dengan keadaan atau segala sesuatu yang ada di sekitar atau sekeliling.

Lingkungan merupakan kesatuan ruang dengan semua benda dan keadaan makhluk hidup termasuk di dalamnya manusia dan perilakunya serta makhluk hidup lainnya. Lingkungan terdiri dari unsur-unsur biotik (makhluk hidup), abiotik (benda mati) dan budaya manusia. Lingkungan yang ada di sekitar anak-anak kita merupakan salah satu sumber belajar yang dapat dioptimalkan untuk pencapaian proses dan hasil pendidikan yang berkualitas. Jumlah sumber belajar yang tersedia di lingkungan ini tidaklah terbatas, sekalipun pada umumnya tidak dirancang serta sengaja untuk kepentingan pendidikan. Lingkungan sangat berperan dalam pertumbuhan dan perkembangan anak. Anak pertama kali akan belajar dan memahami sesuatu dari lingkungannya. Begitu pula halnya dalam belajar dan memahami konsep dan prinsip dalam IPA diperlukan suatu pendekatan yang mampu mewujudkan hal-hal yang diinginkan, yakni salah satunya dengan pendekatan lingkungan. Pendekatan lingkungan berarti mengajak siswa belajar langsung di lapangan tentang topik-topik pembelajaran. Tang mengemukakan adanya hubungan antara manusia dengan lingkungan merupakan hubungan yang saling mempengaruhi sehingga lahir interaksi. Pendekatan lingkungan merupakan suatu interaksi yang berpangkal kepada hubungan antara perkembangan fisik dengan lingkungan sekitarnya. Memanfaatkan lingkungan sebagai sumber belajar berarti siswa menampilkan contoh-contoh penerapan IPA dalam kehidupan seharihari di lingkungan sekitarnya. Dengan kata lain, siswa datang menghampiri sumber-sumber belajarnya (Husamah, 2013: 2-3). Menurut Abulraihan dalam Husamah (2013: 4), lingkungan bisa lingkungan sekolah dan luar sekolah, yang terpenting bahwa aktivitas pembelajaran luar kelas yang dilakukan siswa, guru harus pandai-pandai memilih model atau jenis pembelajaran yang tepat sesuai situasi lingkungan, memperhatikan faktor keamanan karena di alam bebas mempunyai tingkat keriskanan yang tinggi terhadap keselamatan siswa. Lingkungan sekolah adalah suatu wilayah yang sudah dikenal oleh siswa setiapa kali belajar. Hal ini memungkinkan siswa untuk bebas melakukan pengamatan terhadap objek yang menjadi bahan kajian. Lingkungan sekolah dapat juga digunakan sebagai sumber dan sarana belajar. Menurut Association for Educational Communications and Technology (AECT, 1977) dan Banks (1990) dalam Komalasari (2013: 108): Sumber belajar adalah segala sesuatu atau daya yang dapat dimanfaatkan oleh guru, baik secara terpisah maupun dalam bentuk gabungan, untuk kepentingan belajar mengajar dengan tujuan meningkatkan efektivitas dan efisiensi tujuan pembelajaran. 
Selanjutnya AECT dalam Aqib (2013: 56) mengklasifikasikan sumber belajar menjadi 6 sebagai berikut. :

1. Pesan (messages), yaitu informasi yang ditransmisikan oleh komponen lain dalam bentuk ide, fakta, arti, dan data.

2. Orang (peoples), yaitu manusia yang bertindak sebagai penyimpan, pengolah, dan penyaji pesan, misalnya guru, dosen, tutor, peserta didik, tokoh masyarakat dan orang lain yang mungkin berinteraksi dengan peserta didik.

3. Bahan (materials), yaitu perangkat lunak yang mengandung pesan untuk disajikan, misalnya transparansi, slide, film, filmstrip, audio, video, buku, modul, majalah, dan lain-lain.

4. Alat (devices), yaitu perangkat keras yang digunakan untuk penyampaian pesan yang tersimpan dalam bahan, misalnya proyektor slide, overhead, video tape, radio, televisi, dan lain-lain.

5. Teknik (Techniques), yaitu prosedur atau acuan yang disiapkan untuk menggunakan bahan, peralatan, orang dan lingkungan untuk menyampaikan pesan, contohnya instruksional terprogram, belajar sendiri, simulasi, demonstrasi, ceramah, tanya jawab, dan lain-lain.

6. Lingkungan (setting), yaitu situasi sekitar dimana pesan disampaikan, bisa bersifat fisik (gedung sekolah, laboratorium, musium, taman, kebun) maupun non fisik (suasana belajar dan lain-lain)

Sementara itu, Dani, Irfan. (2013), menjelaskan bahwa : Sumber belajar (learning resources) adalah segala macam sumber yang ada di luar diri seseorang (peserta didik) dan yang memungkinkan (memudahkan) terjadinya proses belajar. Kita belajar berbagai pengetahuan, keterampilan, sikap atau norma-norma tertentu dari lingkungan sekitar kita dari guru, dosen, teman sekelas, buku, laboratorium, perpustakaan, dan lain-lain. sumber-sumber belajar itulah yang memungkinkan kita berubah dari tidak tahu menjadi tahu, dari tidak mengerti menjadi mengerti, dan dari tidak terampil menjadi terampil. Selanjutnya, Sanjaya (2016: 174) menyatakan bahwa: Sumber belajar adalah segala sesuatu yang dapat dimanfaatkan oleh siswa untuk mempelajari bahan dan pengalaman belajar sesuai dengan tujuan yang hendak dicapai. Sumber belajar akan menjadi berguna bagi peserta didik maupun guru apabila sumber belajar diorganisir melalui satu rancangan yang memungkinkan seseorang dapat memanfaatkannya sebagai sumber belajar, jika tidak, maka tempat atau lingkungan sekitar tidak memiliki makna apa-apa dalam belajar. Untuk mendapat hasil belajar dengan menggunakan lingkungan sekolah sebagai laboratorium alam dan sebagai sumber belajar perlu diperhatikan langkah-langkah yaitu: (1) Guru menyelidiki lingkungan sekitar, kemudian mencatat hal-hal yang dirasakan dapat dimanfaatkan dalam proses belajar mengajar, (2) Guru membuat perencanaan proses belajar berdasarkan topik yang dipilih, (3) Guru mengorganisasikan siswa tentang tugas yang harus dikerjakan, (4) Memberi penjelasan kepada siswa tentang tugas yang harus dikerjakan, (5) Pemberian tugas pada kelompok atau individu, dan (6) Membuat laporan hasil belajar di lapangan sekolah Dani, Irfan. (2013: 24).

Pemanfaatan lingkungan sebagai sumber pembelajaran lebih bermakna disebabkan para siswa dihadapkan langsung dengan peristiwa dan keadaan yang sebenarnya secara alami, sehingga lebih nyata, lebih faktual, dan kebenarannya 
dapat dipertanggung jawabkan. Banyak keuntungan yang diperoleh dari kegiatan mempelajari lingkungan dalam proses belajar mengajar. Kegiatan belajar lebih menarik dan tidak membosankan siswa duduk di kelas berjam-jam sehingga motivasi belajar siswa akan lebih tinggi. Hakekat belajar akan lebih bermakna sebab siswa dihadapkan langsung dengan situasi dan keadaan yang sebenarnya atau bersifat alami. Sumber belajar menjadi lebih kaya sebab lingkungan yang dapat dipelajari bisa beraneka ragam seperti lingkungan sosial, lingkungan alam, lingkungan buatan, dan lain-lain, dan siswa dapat memahami dan menghayati aspek-aspek kehidupan yang ada di lingkungannya, sehingga dapat membentuk pribadi yang tidak asing dengan kehidupan di sekitarnya, serta dapat memupuk rasa cinta akan lingkungan (Ahmad dan Sudjana, 2016: 114). Selain perpustakaan, kita pun dapat menggunakan keberadaan masyarakat sekitar sekolah atau lingkungan sekolah sebagai sumber balajar. Pemanfaatan lingkungan sekolah sebagai sumber belajar dimanfaatkan jika relevan dengan proses pembelajaran. Untuk pembelajaran IPA, tumbuhan di taman dan kebun sekolah dapat dijadikan sebagai sumber pembelajaran. Lingkungan sebagai sumber belajar dapat dimanfaatkan untuk melihat kondisi fisik lingkungan sekitar dengan segala permasalahannya. Misalnya mengangkat tema pencemaran air, sampah, sungai, danau, gunung, hutan, dan kejadian sosial yang membawa pengaruh bagi kehidupan manusia. Dengan mengangkat isu-isu yang ada dalam lingkungan kehidupan siswa, diharapkan dapat meningkatkan kemampuan siswa dalam mengolah lingkungan fisiknya dan lingkungan sosial agar terjalin hubungan yang harmonis dari keduanya. Kegiatan siswa dalam pembelajaran dengan sumber belajar lingkungan dapat terintegrasi langsung melalui kegiatan observasi, pengamatan, membuktukan sendiri, tanya jawab, diskusi, wawancara. Kegiatan ini dapat dilakukan di dalam maupun di luar kelas (Komalasari, 2013: 138). Menurut Gagne dalam Dahar (1989: 1) lingkungan mempunyai peranan yang penting dalam pembentukan konsep, karena peranannya sebagai stimulus untuk terjadinya suatu respon. Selanjutnya, Komalasari (2013: 139) menjelaskan bahwa konsep-konsep yang abstrak akan lebih mudah dipahami oleh siswa jika siswa mengalaminya secara langsung. Dengan kata lain, pembentukan sikap dan pengembangan keterampilan siswa ditentukan pula oleh interaksinya dengan lingkungan .

Adapun topik-topik pembelajaran yang dipilih berdasarkan penggunaan lingkungan sebagai sumber belajar, mengandung kriteria yaitu pertama, memiliki kesesuaian dengan pokok bahasan / topik ; kedua, dimunculkan berdasarkan minat dan kebutuhan anak ; ketiga, masalah yang dimunculkan berada di lingkungan sekitar siswa ; keempat, menggunakan keterampilan proses berpikir melalui pengalaman belajarnya ; kelima, erat hubungannya dengan lingkungan siswa (Komalasari, 2013: 140).

Menurut Herry (2012: 36) nilai-nilai yang dapat diperoleh dengan menggunakan lingkungan sebagai sumber belajar diantaranya :

a. Lingkungan menyediakan berbagai hal yang dapat dipelajari siswa, memperkaya wawasannya, tidak terbatas oleh empat dinding kelas dan kebenarannya lebih akurat.

b. Belajar akan lebih bermakna sebab siswa dihadapkan dengan keadaan yang sebenarnya dengan memahami dan menghayati aspek-aspek kehidupan yang 
ada di lingkungannya, dapat dimungkinkan terjadinya pembentukan pribadi para siswa seperti cinta akan lingkungan.

c. Kegiatan belajar dimungkinkan akan lebih menarik, tidak membosankan dan menumbuhkan antusiasme siswa untuk lebih giat belajar.

\section{Prestasi Belajar}

Ada beberapa pendapat yang memberikan definisi tentang prestasi belajar. Prestasi belajar berasal dari kata "prestasi" dan "belajar" prestasi berarti hasil yang telah dicapai (Depdiknas, 2014: 895). Dari uraian tersebut dapat diketahui, bahwa prestasi adalah hasil dari suatu kegiatan seseorang atau sekelompok orang yang telah dikerjakan, diciptakan dan menyenangkan hati yang diperoleh dengan jalan bekerja. Selanjutnya pengertian belajar, menurut Lapono (2008:1.14) mengatakan bahwa belajar diartikan sebagai perolehan keterampilan dan ilmu pengetahuan. Pengetahuan mutakhir proses belajar diperoleh dari kajian pengolahan informasi, neurofisiologi, neuropsikologi, dan sain kognitif. Sedangkan menurut Aqib, Zainal. (2013) merumuskan bahwa belajar sebagai suatu proses usaha yang dilakukan oleh individu untuk memperoleh perubahan tingkah laku secara keseluruhan sebagai hasil pengalaman individu tersebut dalam melakukan interaksi dengan lingkungannya.

Menurut Kamus Besar Bahasa Indonesia (2012: 895) berarti :

a) Penguasaan pengetahuan atau keterampilan yang dikembangkan oleh mata

pelajaran, lazimnya ditunjukkan dengan nilai tes atau angka nilai yang diberikan guru.

b) Kemampuan yang sungguh-sungguh ada atau dapat diamati (actual ability) dan yang dapat diukur langsung dengan tes tertentu.

Menurut Sumadi Suryabrata (2014: 297), prestasi dapat puladi definisikan sebagai berikut : "nilai merupakan perumusan terakhir yang dapat diberikan oleh guru mengenai kemajuan / prestasi belajar siswa selama masa tertentu". Jadi, prestasi adalah hasil usaha siswa selama masa tertentu melakukan kegiatan. Menurut pendapat Sumadi Suryabrata (2014), hasil belajar dibagi menjadi empat golongan yaitu :

a) Pengetahuan, yaitu dalam bentuk bahan informasi, fakta, gagasan, keyakinan, prosedur, hukum, kaidah, standar, dan konsep lainya.

b) Kemampuan, yaitu dalam bentuk kemampuan untuk menganalisis, mereproduksi, mencipta, mengatur, merangkum, membuat generalisasi, berfikir rasional dan menyesuaikan.

c) Kebiasaaan dan keterampilan, yaitu dalam bentuk kebiasaan perilaku dan keterampilan dalam menggunakan semua kemampuan.

d) Sikap, yaitu dalam bentuk apresiasi, minat, pertimbangan dan selera.

Dari pendapat di atas dapat disimpulkan bahwa prestasi belajar adalah hasil usaha siswa yang dapat dicapai berupa penguasan pengetahuan, kemampuan kebiasaan dan keterampilan serta sikap setelah mengikuti proses pembelajaran yang dapat dibuktikan dengan hasil tes. Prestasi belajar merupakan suatu hal yang dibutuhkan siswa untuk mengetahui kemampuan yang diperolehnya dari suatu kegiatan yang disebut belajar. 


\title{
Kerangka Berpikir
}

Penulis dapat menggambarkan kerangka berpikir dalam penelitian ini adalah sebagai berikut :

\author{
Lingkungan sekolah \\ Meningkatkan Prestasi belajar
}

\section{Hipotesis Tindakan}

Hipotesis Tindakan dalam penelitian ini adalah pemanfaatan lingkungan sekolah sebagaimedia pembelajaran maka dapat meningkatkan prestasi belajar siswa di SDN Kota Baru Lewoleba.

\section{METODE PENELITIAN}

\section{Subyek, Tempat dan Waktu Penelitian}

Subyek yang diteliti adalah media pembelajaran yang ada di lingkungan sekolah, Tempat penelitian adalah SDN Kota Baru Lewoleba dan waktu penelitian adalah bulan Juli sampai September 2018.

\section{Prosedur Penelitian}

Rencana penelitian tindakan sekolah ini dilakukan dari siklus 1 dan siklus sebagai berikut :

a. Siklus pertama

1. Tahap perencanaan tindakan yang disiapkan antara lain

a) Pedoman penilaian untuk wawancara

b) Melakukan pengamatan awal untuk mengidentifikasi permasalahan yang dihadapi

c) Peneliti akan melakukan wawancara langsung terhadap guru dan siswa.

2. Tahap pelaksanaan tindakan

Pada tahap pelaksanaan tindakan yang dilakukan adalah semua yang disiapkan pada tahap perencanaan tindakan digunakan pada tahap ini.

3. Tahap observasi dan evaluasi, dilaksanakan bersamaan dengan tahap pelaksanaan tindakan. Pada tahap ini digunakan semua pedoman observasi untuk mengumpulkan data tentang dampak atau hasil penelitian.

4. Tahap refleksi, merenungkan ulang pelaksanaan penelitian dan hasil pada siklus pertama. Yang direnungkan adalah :

a) Apa hasil dari Pedoman penilaian untuk wawancara.

b) Bagaimana hasil yang dilakukan dalam pengamatan secara langsung terhadap guru,siswa, lingkungan sekolah dan sekitarnya.

Hasil refleksi ini akan menentukan apakah penelitian diteruskan ke siklus berikutnya atau cukup. 
b. Siklus kedua

Dilakukan berdasarkan hasil refleksi tentang kegiatan siklus pertama, apa saja yang dilakukan pada :

1. Tahap perencanaan tindakan,yang di siapkan antara lain :

a. Pedoman penilaian untuk wawancara

b. Melakukan pengamatan ulang terhadap guru, siswa dan lingkungan sekitar untuk mengidentifikasi ulang permasalahan yang dihadapidalam penelitiaan.

2. Tahap pelaksanaan tindakan : semua yang disiapkan pada tahap perencanaan tindakan digunakan pada tahap ini.

3. Tahap observasi dan evaluasi, dilaksanakan bersamaan dengan tahap pelaksanaan tindakan. Pada tahap ini digunakan semua pedoman observasi untuk mengumpulkan data tentang dampak atau hasil pembelajaran.

4. Tahap refleksi, merenungkan ulang pelaksanaan pembelajaran dan hasil pada siklus pertama.

a) Apa hasil penilaian pedoman untuk wawancara?

b) Apa saja kelemahan atau kekurangan dalam penelitian tadi yang perlu diperbaiki dan apa akibatnya?

Hasil refleksi ini akan menentukan apakah penelitian diteruskan ke siklus berikutnya atau cukup.

\section{Teknik Pengumpulan Data}

a. Teknik pengumpulan data : teknik pengumpulan data yang umum digunakan adalah teknik observasi. Instrumen pengumpulan data : pedoman observasi (berupa daftar cek, skala penilaian catatan kejadian )

b. Tes. Instrumen pengumpulan data penelitian yang valid dan reliable

\section{Teknik Analisa Data}

1. Statistik deskriptif sederhana. Menghitung refleksi dan prosentase hasil penelitian.

a. Siklus pertama :

- Langkah- langkah pelaksanaan penelitian

- Peran guru dan siswa dalam pembelajaran

b. Siklus kedua :

- Langkah- langkah pelaksanaan penelitian

- Peran guru dan siswa dalam pembelajaran

c. Perbandingan antara hasil penelitian siklus pertama dan hasil penelitian siklus kedua :

- Langkah- langkah pelaksanaan penelitian

- Peran guru dan siswa dalam pembelajaran

Aspek hasil meliputi : Prestasi dalam pembelajaran

2. Deskripsi penelitian : Hasil penelitian dengan menggunakan pedoman observasi siklus pertama dan siklus kedua di deskripsikan secara verbal. Hasil observasi dibuat transkripsi observasi. 


\section{HASIL PENELITIAN DAN PEMBAHASAN \\ Hasil Penelitian \\ Siklus I}

1. Tahap Perencanaan

Sebelum melaksanakan kegiatan penelitian tindakan sekolah, peneliti harus mempersiapkan perencanaan yang baik. Hal-hal yang disiapkan adalah jadwal penelitian, angket wawancara, pedoman penilain dan hal-hal yang berhubungan dengan kegiatan penelitian. Setelah semua perencanaan sudah disiapkan maka peneliti mulai melaksanakan penelitian. Penelitian ini direncanakan pada bulan Agustus sampai dengan bulan Oktober 2018. Rencana penelitian ini akan melalui 2 siklus dan masing- masing siklus mengalami dua kali penelitian. Penelitian ini akan dilaksanakan langsung oleh kepala sekolah yang dibantu oleh salah seorang guru senior sebagai observer untuk mengamati dan menilai apa yang diteliti. Subyek yang akan dijadikan penelitian adalah media yang ada di lingkungan sekolah yang dimanfaatkan guru untuk meningkatkan proses belajar mengajar di sekolah. Media pembelajaran yang ada dilingkungan SDN Kota Baru cukup banyak seperti lapangan olaraga, tanaman, air, batu-batuan, tanah, pasir, perpustakaan. Alat olaraga, alat musik, kantin sekolah, tempat sampah, sampah daur ulang dan media pembelajaran lain yang disiapkan sekolah. Semua media yang ada tinggal dimanfaatkan guru untuk kegiatan yang berhubungan dengan penerapan metode sesuai dengan materi dalam pembelajaran.Rencana penelitian baik siklus I maupun siklus II adalah pada mata pelajaran Matematika dan IPA. Untuk pelajaran Matematika pada kelas I dan kelas II dan III sedangkan pelajaran IPA pada kelas IV dan Vdan VI.

2. Tahap Pelaksanaan

Pelaksanaan penelitian ini dimulai pada bulan Agustus minggu pertama dan minggu kedua melalaui pelaksanaan siklus I.

\section{- Pertemuan Pertama}

Yang dilakukan pada pertemuan pertama adalah kepala sekolah sebagai peneliti mengadakan pertemuan dan menyampaikan kepada observer dan guru- guru yang ada di SDN Kota Baru tentang hal- hal yang harus diteliti adalah tentang media pembelajaran yang ada disekitar lingkungan sekolah yang akan dimanfaatkan guru sebagai media pembelajaran sesuai dengan metode dan materi yang diajarkan sehingga dengan pemanfaatan media di lingkungan sekolah dapat mengajak siswa untuk terjun langsung atau mengamati atau mendemonstrasikan atau mempratekan langsung sehingga siswa merasa lebih dekat dan mudah. Kepala sekolah juga menyampaikan kepada para guru tentang penelitian yang dilaksanakan dengan mengambil tema tentang pemanfaatan media pembelajaran di lingkungan sekolah. Peneliti juga menyampaikan agar para guru harus kreatif dalam menerapkan metode dan membaca peluang dengan hal-hal yang dapat menunjang kegiatan belajar disekitarnya tanpa mengeluarkan biaya atau tenaga ekstra. Dengan demikian dapat meningkatkan prestasi belajar siswa di SDN Kota Baru. Pelaksanaan siklus I pada pertemuan 
pertama cukup baik, para guru menerima dengan baik dan akan mendukung peneliti dalam melaksanakan penelitian di sekolah.

\section{- Pertemuan Kedua}

Setelah hasil pertemuan pertama diterima dengan baik oleh observer dan para guru, maka pada pertemuan kedua ini kepala sekolah mulai melakukan penelitian. Pada pertemuan kedua ini, peneliti melaksanakan penelitian selama seminggu. Untuk mempermuda proses penelitian, kepala sekolah membuat jadwal penelitian. Hari senin diadakan penelitian pada dua kelas yaitu kelas I dan kelas II. Hari selasa penelitian di kelas III dan IV. Hari rabu penelitian di kelas V dan VI. Waktu yang digunakan setiap kali pertemuan sebanyak 2 jam. Hal yang akan diteliti adalah pengamatan secara langsung dan menjawab pertanyaan sesuai dengan angket yang sudah disiapkan. Angket penilaian dapat dilihat pada hasil pengamatan penelitian dibawah ini.

\section{Tahap Pengamatan}

Pada penelitian ini hal guru dalam hal ini memanfaatkan lingkungan sekolah sebagai media pembelajaran, maka yang diamati adalah guru yang ada di SDN Kota Baru. Hasil pengamatan dan hasil nilai berdasarkan angket yang disiapkan oleh peneliti yang dibantu oleh salah seorang guru senior untuk memberikan penilaian.

Tabel 1. Deskripsi Hasil Pengamatan Aktifitas Guru Pada Siklus I

\begin{tabular}{|c|c|c|c|c|c|c|c|}
\hline \multirow{2}{*}{ No } & Pertanyaan & I & II & III & IV & V & VI \\
\hline 1 & Penerapan Metode pembelajaran & 2 & 2 & 2 & 2 & 2 & 2 \\
\hline 2 & $\begin{array}{c}\text { Penggunaan media } \\
\text { pembelajaran }\end{array}$ & 2 & 2 & 2 & 2 & 2 & 2 \\
\hline 3 & $\begin{array}{c}\text { Media pembelajaran menarik } \\
\text { bagi siswa }\end{array}$ & 2 & 2 & 2 & 2 & 2 & 2 \\
\hline 4 & $\begin{array}{c}\text { Aktifitas siswa dalam proses } \\
\text { pembelajaran }\end{array}$ & 2 & 2 & 2 & 3 & 3 & 3 \\
\hline 5 & $\begin{array}{c}\text { Media pembelajaran } \\
\text { meningkatkan prestasi belajar } \\
\text { siswa }\end{array}$ & 2 & 2 & 2 & 2 & 3 & 3 \\
\hline 6 & Penguasaan materi pembelajaran & 3 & 3 & 3 & 3 & 3 & 3 \\
\hline & JUMLAH & 13 & 13 & 13 & 13 & 15 & 15 \\
\hline & Rata-Rata & 2,16 & 2,16 & 2,16 & 2,16 & 2,5 & 2,5 \\
\hline \multicolumn{2}{|c|}{ Prosentase (\%) } & 36,11 & 36,11 & 36,11 & 36,11 & 41,66 & 41,66 \\
\hline & Predikat & $\mathrm{C}$ & $\mathrm{C}$ & $\mathrm{C}$ & $\mathrm{C}$ & $\mathrm{C}$ & $\mathrm{C}$ \\
\hline
\end{tabular}

Sumber : Hasil Penelitian, diolah (2018)

Keterangan :

$\begin{array}{ll}\text { Sangat Baik (SS) } & =80-100 \\ \text { Baik (B) } & =60-79 \\ \text { Cukup (C) } & =30-69 \\ \text { Kurang (D) } & =0-29\end{array}$

Pada tabel dibawah atas menjelaskan bahwa hasil pengamatan observer pada kelas I sampai kelas VI, Guru dalam kegiatan proses belajar mengajar di sekolah dengan menerapkan metode pembelajaran dan menggunakan media dalam 
hal ini pemanfaatan lingkungan sekolah sebagai media pembelajaran rata-rata mendapat predikat cukup. Hal ini disebabkan guru sendiri lebih menggunakan pola lama dalam pembelajaran dan menggunakan metode atau media yang ada di buku atau media gambar sesuai dengan materi yang diajar ketimbang menggunakan media yang ada di lingkungan sekitar sekolah. Dengan demikian mengakibatkan siswa merasa bosan dan cenderung untuk belajar. Siswa mungkin merasa bosan dengan suasana kelas yang kurang menarik. Dengan demikian hasil yang dicapai atau prestasi yang dicapai belum meningkat dengan maksimal, masih rata- rata standar KKM.

Hasil pengamatan aktifitas guru dalam kegiatan belajar yang diamati observer dan kepala sekolah secara langsung, perlu ditingkatkan lagi pada penelitian atau pertemuan di siklus II, sehingga hasil yang dicapai jauh lebih baik lagi. Untuk itu kepala sekolah akan melakukan penelitian kembali pada pelaksanaan siklus II yang direncanakan pada bulan September minggu pertama dan minggu kedua.

\section{Tahap Refleksi}

Dari tahap perencanaan sampai dengan tahap pelaksanaan siklus I, hasil yang dicapai cukup baik. Hasil pengamatan langsung dan hasil pengamatan dari observer pada masing- masing kelas menemukan bahwa banyak guru telah menerapkan metode tetapi ada metode yang belum tepat sesuai dengan materi dan guru- guru jarang menggunakan media pembelajaran, Mereka hanya menggunakan media pembelajaran yang ada di buku. Di kelas I dan II untuk menunjang kegiatan belajar guru pada umumnya menggunakan media untuk berhitung dan membaca. Untuk membantu siswa berhitung menggunakan media dari biji- bijian atau dari lidi. Dengan demikian untuk mengatasi kekurangan ini kepala sekolah memberikan penjelasan atau motivasi kepada para guru untuk memanfaatkan media yang ada disekitarnya sehingga dapat menunjang dan meningkatkan prestasi belajar baik guru maupun siswa. Melihat kekurangan atau kelemahan yang ada pada pelaksanaan siklus I maka peneliti akan meningkatkan lagi perencanaan yang baik pada pelakanaan siklus II nanti.

\section{Siklus II}

a. Tahap Perencanaan

Pelaksanaan siklus I sudah berjalan dengan baik namun masih banyak kekurangan yang harus direncanakan dengan matang. Pada tahap perencanaan siklus II, hal- hal yang disiapkan sama dengan siklus II tetapi kepala sekolah harus mengamati langsung kegiatan pembelajaran dan memberikan motivasi atau atau dukungan penuh, sehingga para guru benar- benar melaksanakan dengan baik. Rencana pelaksanaan siklus II di mulai pada minggu pertama dan minggu kedua bulan September 2018. Pada minggu pertama kepala sekolah mengadakan penelitian untuk kelas I sampai kelas III dan akan mengamati secara langsung kegiatan yang dilakukan guru. 
b. Tahap Pelaksanaan

- Pertemuan Pertama

Pada pertemuan pertama ini, kepala sekolah akan mengadakan penelitian untuk guru kelas I sampai kelas III selama 3 hari yaitu hari Senin sampai hari Rabu. Pada hari Senin kepala sekolah mulai melaksanakan penelitian di kelas I yang dibantu oleh observer. Kepala sekolah melakukan pengamatan langsung kegiatan pembelajaran. Peleksanaan ini berlangsung selama 2 jam. Pada penelitian dari hari Senin sampai Rabu, jam pelajaran pertama guru melaksanakan pembelajaran Matematika dengan belajar berhitung pada siswa kelas I, II dan kelas III. Guru mengajak siswa untuk belajar diluar kelas. Siswa dituntun untuk duduk di halaman sekolah dibawah pohon. Guru menjelaskan kepada siswa dan memulai pelajaran. Guru mengajar siswa untuk berhitung sesuai dengan petunjuk dan siswa melaksanakannya dengan cukup baik tetapi ada siswa yang masih bingung dan salah mengambil media yang di tunjuk. Siswa terlihat lebih bersemangat dan antusias mengikuti pelajaran dan suasana terlihat hidup dan menarik. Gurupun semangat memberikan petunjuk kepada siswa. Tetapi ada kekurangan dimana siswa lebih banyak bermain dan gaduh. Dari hasil pengamatan media yang digunakan untuk berhitung adalah batu- batuan kecil, tanaman, tempat sampah, lidi, menghitung meja kursi, siswa sendiri dan media lain yang ada di lingkungan sekolah. Hal ini dilakukan guru kelas I dan II. Pada kelas III guru mengajak siswa untuk berdiskusi bersama dengan teman lain dengan menghitung benda- benda yang ada di sekitar sekolah sebagai media untuk berhitung. Hasil yang dicapai baik dan memuaskan. Pada hari Kamis sampai Sabtu, kepala sekolah mengadakan penelitian di kelas IV sampai kelas VI. Penelitian dilaksanakan pada jam pelajaran pertama. Dalam pengamatan langsung selama tiga hari, guru mengajak siswa untuk belajar di luar kelas. Penelitian ini untuk pelajaran IPA. Pada kelas IV sampai dengan kelas VI guru menerapkan metode diskusi dan metode demonstrasi dengan mengajak siswa untuk menggunakan media yang ada di lingkungan sekitar sekolah sesuai dengan materi yang diajarkan. Hasil yang dicapai memuaskan karena para guru menerapkan metode dan media dengan tepat sesuai dengan materi yang diajarkan dan hasil yang dicapai dapat meningkatkan prestasi dan semangat belajar siswa.

- Pertemuan Kedua

Pada pertemuan kedua, kepala sekolah menyuruh para guru dari masing-masing kelas untuk membuat laporan selama kegiatan dan hasilnya akan diserahkan kepada peneliti sebagai kepala sekolah untuk memberikan penilaian. Hasil kegiatan dapat dilihat pada tabel di bawah ini :

Tabel 2. Hasil Kegiatan Guru Kelas Membuat Laporan

\begin{tabular}{|c|c|c|c|c|}
\hline No & Kelas & $\begin{array}{c}\text { Mata } \\
\text { Pelajaran }\end{array}$ & Penilaian & Keterangan \\
\hline 1 & I & Matematika & B & Baik \\
\hline 2 & II & Matematika & B & Baik \\
\hline 3 & III & Matematika & B & Baik \\
\hline
\end{tabular}


Lanjutan Tabel 2. Hasil Kegiatan Guru Kelas Membuat Laporan

\begin{tabular}{|c|c|c|c|c|}
\hline No & Kelas & $\begin{array}{c}\text { Mata } \\
\text { Pelajaran }\end{array}$ & Penilaian & Keterangan \\
\hline 4 & IV & IPA & B & Baik \\
\hline 5 & V & IPA & SB & Sangat Baik \\
\hline 6 & VI & IPA & SB & Sangat Baik \\
\hline
\end{tabular}

Sumber : Hasil Penelitian, diolah (2018)

\section{c. Tahap Pengamatan}

Hasil pengamatan observer pada pelaksanaan siklus II, pada kelas I sampai IV mendapat nilai Baik dan pada kelas V dan VI mendapat nilai sangat baik. Hal ini dapat dilihat pada tabel hasil pengamatan observer di bawah ini :

Tabel 3. Deskripsi Hasil Pengamatan Aktivitas Guru Pada Siklus II

\begin{tabular}{|c|c|c|c|c|c|c|c|}
\hline \multirow{2}{*}{ No } & \multirow{2}{*}{ Pertanyaan } & \multicolumn{6}{|c|}{ KELAS } \\
\hline & & I & II & III & IV & V & VI \\
\hline 1 & $\begin{array}{l}\text { Penerapan Metode } \\
\text { pembelajaran }\end{array}$ & 3 & 3 & 3 & 3 & 4 & 4 \\
\hline 2 & $\begin{array}{l}\text { Penggunaan media } \\
\text { pembelajaran }\end{array}$ & 3 & 3 & 3 & 3 & 4 & 4 \\
\hline 3 & $\begin{array}{l}\text { Media pembelajaran } \\
\text { menarik bagi siswa }\end{array}$ & 2 & 2 & 3 & 3 & 4 & 4 \\
\hline 4 & $\begin{array}{l}\text { Aktifitas siswa dalam } \\
\text { proses pembelajaran }\end{array}$ & 2 & 2 & 3 & 3 & 3 & 3 \\
\hline 5 & $\begin{array}{l}\text { Media pembelajaran } \\
\text { meningkatkan prestasi } \\
\text { belajar siswa }\end{array}$ & 3 & 3 & 3 & 3 & 3 & 3 \\
\hline 6 & $\begin{array}{l}\text { Penguasaan materi } \\
\text { pembelajaran }\end{array}$ & 3 & 3 & 3 & 3 & 4 & 4 \\
\hline & JUMLAH & 16 & 16 & 18 & 18 & 22 & 22 \\
\hline & Rata-Rata & 2,66 & 2,66 & 3 & 3 & 3,66 & 3,66 \\
\hline & Prosentase $(\%)$ & 44,33 & 44,33 & 50 & 50 & 61,11 & 61,11 \\
\hline & Predikat & $\mathrm{C}$ & $\mathrm{C}$ & $\mathrm{C}$ & $\mathrm{C}$ & $\mathrm{B}$ & B \\
\hline
\end{tabular}

Sumber : Hasil Penelitian, diolah (2018)

Keterangan :

$\begin{array}{ll}\text { Sangat Baik (SS) } & =80-100 \\ \text { Baik (B) } & =60-79 \\ \text { Cukup (C) } & =30-69 \\ \text { Kurang (D) } & =0-29\end{array}$

Dari deskripsi hasil pengamatan aktifitas guru, maka pada kelas I sampai IV hasil yang dicapai cukup baik dan pada kelas V dan VI hasil yang dicapai baik dan memuaskan. Walaupun hasil pengamatan aktifitas guru dari observer pada siklus II memuaskan namun perlu ditingkatkan terus dalam kegiatan pembelajaran setiap hari sehingga prestasi yang dicapai baik siswa maupun guru lebih baik lagi.

\section{Refleksi}

Refleksi yang diambil dari pelaksanaan kegiatan siklus II pada pertemuan pertama dan kedua baik dan memuaskan walaupun masih ada kekurangan yang 
harus diperbaiki dan kepala sekolah memberikan motivasi kepada para guru untuk lebih banyak mencari sumber referensi tentang metode pembelajaran dan media pembelajaran yang akan membantu guru dalam memecahkan masalah dalam kegiatan belajar mengajar dan melatih guru untuk lebih professional dalam kinerjanya sebagai guru sehingga dapat meningkatkan kualitas bagi dirinya dan dapat meningkatkan prestasi bagi anak didiknya.

\section{KESIMPULAN DAN SARAN Kesimpulan}

Setelah membahas dari latar belakang sampai dengan pembahasan maka dapat disimpulkan bahwa pemanfaatan lingkungan sekolah sebagai media pembelajaran perlu ditingkatkan lagi sehingga guru tidak perlu menggunakan media yang harus mengeluarkan biaya untuk membelinya. Dengan demikian perlu dukungan dari pihak sekolah untuk melengkapi dan menjaga media pembelajaran yang ada di sekitar lingkungan sekolah.

\section{Saran}

a. Bagi Siswa dan Guru : agar siswa dan guru memanfaatkan lingkungan sekolah sebagai media pembelajaran dan siswa berperan aktif dan mendukung guru dalam kegiatan pembelajaran.

b. Bagi Sekolah : agar dapat mendukung dan mencontoh pemanfaatan lingkungan sekolah yang dilakukan guru sebagi sumber pembelajaran yang dapat meningkatkan kualitas sekolah kedepannya.

\section{DAFTAR PUSTAKA}

Amalia, Nurin Hanifati. 2015. Upaya Pelestarian Lingkungan Melalui Program Adiwiyata Sebagai Sumber Belajar Peserta Didik (Study Kasus SMP NEGERI 2 DEPOK). Skripsi, Jakarta : UIN Syarif Hidayatullah .

Aqib, Zainal. 2013. Model-model, Media, dan Strategi Pembelajaran Kontekstual (Inovatif). Bandung: Penerbit Yrama Widya.

Ardiyani, Avira Mufti. 2011. Pengaruh Lingkungan Sekolah dan Minat Belajar Siswa terhadap Prestasi Belajar Ekonomi Siswa Kelas VIII MTs I'anah Futuhiyah Bodeh Pemalang Tahun 2010/2011. (Skripsi) tidak dipublikasikan.

Dani, Irfan. 2013. Pendekatan Resource Based Learning. Tersedia pada laman web: http://pustaka.pandani.web.id/2013/10/pendekatan-resourcebasedlearning.html. Di akses Sabtu, 26 Mei 2018 Pukul 21.00 WIB.

Daryanto, Suprihatin, Agung. 2013. Pengantar Pendidikan Lingkungan Hidup. Yogyakarta: Gava Media.

Departemen Pendidikan Nasional. 2014. Kamus Besar Bahasa Indonesia Cetakan ke delapan Belas Edisi IV. Jakarta : Gramedia Pustaka Utama

Hamalik, O. 2010. Proses Belajar Mengajar. Jakarta : PT. Bumi Aksara.

Herry. 2012. Analisis Laporan Keuangan. Jakarta: PTBumi Aksara.

Hidayat, A., 2010. Ilmu Lingkungan. Jakarta: Universitas Mercu Buana.

Husamah. 2013. Pembelajaran Luar Kelas (OUTDOOR LEARNING). Jakarta: Prestasi Pustaka. 
Kamus Besar Bahasa Indonesia 2012-2015. Arti Kata Sekolah Tinggi, (Online),

(Kamus Besar Bahasa Indonesia (KBBI) Online - arti kata sekolah, diakses 8 September 2015 pukul 1.58)

Komalasari, Kokom. 2013. Pembelajaran Kontekstul : Konsep dan Aplikasi. Bandung : PT Refika Adiatama

Lapono, Nabisi, dkk. 2008. Belajar dan Pembelajaran SD. Direktorat Jenderal Pendidikan Tinggi. Departemen Pendidikan Nasional.

Sanjaya, W. 2016. Strategi Pembelajaran. Jakarta: Prenadamedia Group

Sumadi Suryabrata. 2014. Psikologi Pendidikan. Jakarta: Rajagrafindo Persada 